\title{
RESEARCH PAPER \\ Energy potential of vine shoots in La Rioja (Spain) and their dependence on several viticultural factors
}

\author{
Manuel Antonio Mendívil ${ }^{1}$, Pedro Muñoz ${ }^{2}$, María Pilar Morales ${ }^{2}$, and \\ Manuel C. Juárez Castelló1 \\ ${ }^{1}$ Escuela Técnica Superior de Ingeniería Industrial, Universidad de La Rioja. Luis de Ulloa 4, \\ 26002-Logroño, Spain. \\ ${ }^{2}$ Facultad de Ingeniería, Universidad Autónoma de Chile. 5 Poniente 1760, Talca, Chile.
}

\begin{abstract}
M.A. Mendívil, P. Muñoz, M.P. Morales, and M.C. Juárez Castelló. 2015. Energy potential of vine shoots in La Rioja (Spain) and their dependence on several viticultural factors. Cien. Inv. Agr. 42(3): 443-451. Each year, viticulture generates thousands of tons of vine shoots in the Spanish La Rioja region without an adequate system for their use. This study attempts to increase the value of this residual biomass, mainly for energy generation. To this end, a representative sampling of vine varieties and vineyards in the region was taken and later thermochemically characterized, measuring moisture, ash content percentage, elemental composition and higher heating value (HHV) among all sampled lots. From these tests, only the variety factor of the vine exhibited any statistically significant influence. A correlation has been formulated to express the higher heating value of vine shoots in terms of their elemental composition, obtaining an estimate with a mean absolute error of $1 \%$ and a near zero mean bias error. Finally, because the annual amount of vine shoots generated in the La Rioja region is known, the energetic potential of this biomass has been estimated at 1,400,000 GJ per year, and a map is presented to show the energy density of this waste material from each municipality.
\end{abstract}

Key words: Energy potential, higher heat value, thermochemical characterization, vine shoots.

\section{Introduction}

Vine cultivation (Vitis vinifera) and the subsequent production of wine are the real economic drivers in the La Rioja region in northern Spain, accounting for approximately $20 \%$ of its exports. Vineyards cover 42,000 hectares of the territory of the Autonomous Community of La Rioja, according to data published in 2013 by the Consejo Regulador de la Denominación de Origen Calificada Rioja

Received February 11, 2015. Accepted November 16, 2015. Corresponding author: pmunozv@uautonoma.cl (the Control Board for the Designation of Rioja Origin). This board annually quantifies the area dedicated to vineyards as well as the yields of harvested grapes in kilograms in all the municipalities covered by the designation of origin. The extension of the vineyards in La Rioja has not changed significantly in recent years because this crop is strictly regulated by the European Union. The conservative 2010 estimates indicate that more than 150,000 metric tons of vine shoots were produced from the La Rioja vineyards (Mendívil et al., 2011). 
Vine shoots have already been proposed as a possible contributor to power generation in Spain (Mediavilla et al., 2009; San José et al., 2013). To this end, it is essential to understand the chemical composition of this waste material prior to its use. However, the scientific literature has so far provided little information about the chemical characterization of vine shoots; furthermore, existing studies routinely ignore the nature and the agronomic conditions of the grapevines from which the samples were extracted.

The magnitude that best describes the energetic behavior of a material is called its higher heating value (HHV), which refers to the heat released during combustion with water (both contained in the fuel and generated in a liquid state). The scientific literature describes several methods for predicting the HHV of biomass samples using various types of analysis: biochemical composition, immediate analysis (ashes, volatile compounds and fixed carbon) and elemental analysis $(\mathrm{C}, \mathrm{H}, \mathrm{O}, \mathrm{N}, \mathrm{S})$. Generally, these correlations have not been developed from the measured values of the HHV in perfectly controlled circumstances, but rather make use of scattered data sets collected from unrelated studies (Annamalai et al., 1987; Tillman, 1987; Jenkins et al., 1998; Channiwala and Parikh, 2002; Sheng and Azevedo, 2005).

Taking these data into account, the objectives of this study are as follows: the thermochemical characterization of vine shoot samples from all vine varieties grown in La Rioja to determine their elemental composition and their HHV through pertinent tests; the detection of the possible influence of certain viticultural factors on the HHV of vine shoots, such as the vine variety, vine cultivation method, density of cultivation and other agronomic factors; the formulation of an empirical correlation that allows for the determination of the HHV of vine shoots through their elemental composition; and the estimation of the energy potential of vine shoots in the region.

\section{Materials and methods}

Vine shoots samples were taken from the network of experimental vineyards in the Servicio de Investigación y Desarrollo Tecnológico Agroalimentario del Gobierno de La Rioja (Food and Agricultural Technological Research and Development Service of the Government of La Rioja). These vineyards are distributed throughout all three areas in which the Qualified Designation of Rioja Origin is divided.

The subsequent analyses were carried out in the Laboratorio Regional del Gobierno de La Rioja (Regional Laboratory of the Government of La Rioja), accredited based on the UNE-EN ISO/ IEC 17025 regulation, and in the laboratories of the Departments of Chemistry and Mechanical Engineering at the University of La Rioja.

The vineyards in the region have an overwhelming majority of red varieties and, among these, the red Tempranillo variety is very prominent, whereas others have been grown in only trial fields. Furthermore, two types of vineyard cultivation methods coexist:

- The Gobelet, or bush method. Historically, this system is the most widespread cultivation system in Spain and throughout the Mediterranean basin.

- Trellis cultivation systems (in single or bilateral cordons), where the vines are vertically driven by wires and poles.

After the harvest of the 2010 crop, over two days, 75 lots of 12 vine shoots were collected. In each chosen vineyard, different vine varieties were sampled, and the shoots were pruned from various locations within each vine variety. For each of these lots, the following factors were considered:

- Vine variety: red (Tempranillo, Garnacha tinta, Mazuelo, Graciano, Merenzao, Monastel, Turruntés, Cabernet Sauvignon) or white (Viura, 
Malvasia, Garnacha blanca, Tempranillo blanco, Calagraño, Maturana blanca).

- Cultivation method: bush system or trellis system (in single or bilateral cordons).

- Field Density.

- Age of the vineyard.

The lots were moved to a warehouse equipped with a temperature and humidity control system, where they were allowed to dry naturally for three months. After this drying period, each lot was mechanically crushed and divided into four portions. Two opposite portions were mixed, and two samples were taken. The first sample was kiln dried at $105^{\circ} \mathrm{C}$ and then ground in two stages to smaller than $0.25 \mathrm{~mm}$, whereas the second one was stored.

\section{Moisture analysis of the samples}

In addition to the controls performed during natural and forced drying, the residual moisture content of the samples was determined prior to the analysis based on the European standard EN 14774-3:2009 (European Committee for Standardization, 2009a). In this article, the moisture of the shoots refers to the wet basis at pruning time.

\section{Analysis of ash content}

An ash content analysis was carried out according to European standard EN 14775:2009 (European Committee for Standardization, 2009 b) by calcinating the samples at $550{ }^{\circ} \mathrm{C}$ in a muffle furnace.

\section{Elemental analysis (C, $H, O, N, S)$}

The European standard used to determine the content of C, H and N was EN 15104:2011 (European Committee for Standardization, 2011). The content analysis of $\mathrm{C}, \mathrm{H}, \mathrm{N}$ and $\mathrm{S}$ was carried out using an elemental analyzer unit, TruSpec Elemental Determinator, by LECO Corp., St. Joseph, Michigan, USA.

\section{Measurement of higher heating value (HHV)}

To determinate the HHV of the vine shoot lots, a LECO AC-300 calorimeter was used, following the f European standard EN 14918:2009 (European Committee for Standardization, 2009c). The Benzoic acid tablets used for calibration were supplied by the Bureau of Analysed Samples, Ltd., with their calorific value previously certified by Pattinson \& Stead Ltd.

\section{Statistical analysis}

A statistical analysis of the results was performed to determine the significance (or lack thereof) of the observed dependencies between the different study variables.

The influence of the various factors on the HHV was determined with an analysis of variance (ANOVA). When such analysis was not possible, nonparametric methods were used, such as the Kruskall-Wallis test and the Mann-Whitney U test. The software Statistica 9.0, by StatSoft Inc., was used to perform these tests.

\section{Estimation of HHV from the elemental analysis}

In the scientific literature, there are numerous proposed methods for calculating the HHV of a biomass sample, which can be estimated either from its biochemical composition, from immediate analysis or from its elemental analysis. Special attention was paid only to the latter because correlations based on biochemical composition or based on a simple immediate analysis have proven to be less accurate for all types of biomass tested (Sheng and Azevedo, 2005). 
To evaluate the precision of the equations that were developed, the estimated HHV value $\left(\mathrm{HHV}_{\mathrm{E}}\right)$ for each sample was compared with the analytically measured $\mathrm{HHV}$ value $\left(\mathrm{HHV}_{\mathrm{M}}\right)$. Several statistical parameters were used to carry out these comparisons:

- Average Absolute Error (AAE):

$$
A A E=\frac{1}{n} \cdot \sum\left|\frac{H H V_{E}-H H V_{M}}{H H V_{M}}\right| \cdot 100
$$

- Average Bias Error (ABE):

$$
A B E=\frac{1}{n} \cdot \sum\left(\frac{H H V_{E}-H H V_{M}}{H H V_{M}}\right) \cdot 100
$$

- Standard Deviation of Prediction Error:

$$
\begin{aligned}
& S D E=\sqrt{\sum \frac{\left(H H V_{E} \quad H H V_{M}-\overline{B I A S}\right)^{2}}{n-1}} \\
& \overline{B I A S}=\frac{1}{n} \cdot \sum\left(H H V_{E}-H H V_{M}\right)
\end{aligned}
$$

In the aforementioned expressions, $\mathrm{n}$ is the number of samples. Although AAE shows the absolute error of the prediction, ABE provides an idea about whether the correlation is overestimating or underestimating the value. SDE evaluates the accuracy of the prediction. These statistical parameters have been widely used for analyzing errors in the correlations based on the scientific literature (Channiwala and Parikh 2002; Sheng and Azevedo, 2005; Friedl et al., 2005).

\section{Data sources for estimating energy potential}

In addition to the data periodically published by the Consejo Regulador de la Denominación de Origen Calificada Rioja, data supplied by the Oficina de Viñedos (Vineyard Office, an agency under the Department of Agriculture of the Government of
La Rioja) was also reviewed for accuracy. These data include information from each of the farms in La Rioja dedicated to the cultivation of vines, with a special emphasis on the surface of each farm and its field density From these data, we can calculate the density of vines per hectare in each municipality and we can generate a reliable estimation of the total number of vines in the region and their spatial distribution.

In viticulture, several indexes relate the vigor of the vines or grape production to the weight of wood (vine shoots) that is generated from the annual pruning (Martinez de Toda, 2007). These rates can vary, due to the diversity of agronomic practices, within a range of 0.4 to $0.9 \mathrm{~kg}$ of vine shoots per vine, although some authors raise this value to $1.3 \mathrm{~kg}$ per vine (Ramos, 2009). This study estimated an average production of 0.85 $\mathrm{kg}$ per vine.

\section{Results and discussion}

Thermochemical characterization of the samples

A summary of the obtained results is shown in Table 1, where the vine variety and its contribution to the total production in La Rioja are specified. The reflected values do not differ much from those reported by the few existing studies in the scientific literature where varietal diversity was also considered (Ebeling and Jenkins, 1985).

Influence of different viticultural factors on the HHV of vine shoots

Of all the studied factors, only the vine variety exhibited a statistically significant influence on the HHV of the pruned shoots, as confirmed after a statistical analysis. Because the conditions that were needed to ensure the reliability of the ANOVA were not fully met, a nonparametric statistical 
Table 1. Average elemental composition per variety, based on cultivated area in La Rioja.

\begin{tabular}{lcccccccc}
\hline & $\begin{array}{c}\text { Surface } \\
\text { (ha) }\end{array}$ & $\begin{array}{c}\text { Moisture } \\
(\%)\end{array}$ & Ashes $(\%)$ & $\mathrm{C}(\%)$ & $\mathrm{H}(\%)$ & $\mathrm{N}(\%)$ & $\mathrm{S}(\%)$ & $\begin{array}{c}\mathrm{HHV}(\mathrm{kJ} \\
\left.\mathrm{kg}^{-1}\right)\end{array}$ \\
\hline Red varieties: & & & & & & & & \\
Tempranillo & 33,970 & 52.38 & 2.99 & 46.21 & 6.02 & 0.76 & 0.06 & 18,778 \\
Garnacha tinta & 5,068 & 55.48 & 3.82 & 45.85 & 6.27 & 0.79 & 0.05 & 18,566 \\
Mazuelo & 1,102 & 51.80 & 3.07 & 46.47 & 6.09 & 0.76 & 0.05 & 18,839 \\
Graciano & 678 & 51.88 & 2.92 & 46.36 & 6.15 & 0.74 & 0.05 & 18,794 \\
Merenzao & $*$ & 49.96 & 2.36 & 46.23 & 5.82 & 0.68 & 0.04 & 18,604 \\
Monastel & $*$ & 48.34 & 2.77 & 45.96 & 5.86 & 0.79 & 0.04 & 18,531 \\
Turruntés & $*$ & 49.59 & 2.87 & 47.54 & 5.18 & 0.70 & 0.05 & 18,783 \\
Cabern. Sauvignon & $*$ & 50.45 & 3.04 & 46.68 & 6.05 & 0.78 & 0.06 & 18,725 \\
White varieties & & & & & & & & \\
Viura & 2,613 & 50.52 & 2.98 & 46.13 & 6.05 & 0.70 & 0.04 & 18,801 \\
Malvasía & 48 & 51.25 & 3.03 & 46.06 & 5.90 & 0.82 & 0.05 & 18,779 \\
Garnacha blanca & 17 & 54.59 & 3.39 & 45.99 & 6.04 & 0.74 & 0.05 & 18,515 \\
Tempranillo blanco & $*$ & 52.96 & 2.96 & 46.43 & 6.07 & 0.78 & 0.05 & 18,918 \\
Calagraño & $*$ & 52.76 & 3.14 & 45.67 & 6.06 & 0.81 & 0.04 & 18,641 \\
Maturana blanca & $*$ & 48.73 & 3.09 & 46.58 & 5.91 & 0.75 & 0.05 & 18,786 \\
\hline
\end{tabular}

The amount of ash and elements are expressed in \% of weight on a dry basis.

Varieties marked $(*)$ are grown only on trial fields.

test, the Kruskal-Wallis test, was performed to confirm the result. In Figure 1, it can be clearly observed that the Garnacha variety (second in importance in La Rioja after the Tempranillo variety) has a measurably lower HHV. Likewise, it appeared that none of the other studied factors (vineyard cultivation method, farm layout and age of the vineyard) had a significant influence on the HHV of the vine shoots.

Relationship between the HHV of the shoots and their elemental composition

Focusing on the predominant Tempranillo variety, the study clearly found that each of the considered elementary components influenced the measured $\mathrm{HHV}$ of the vine shoots very differently. In Figure 2, we show the evolution of the measured $\mathrm{HHV}$ compared to the percentage of $\mathrm{C}, \mathrm{H}$ and ash content (always measured on a dry basis). Although the impact of the amount of $\mathrm{H}$ was not clear, the amount of $\mathrm{C}$ marked an upward trend,

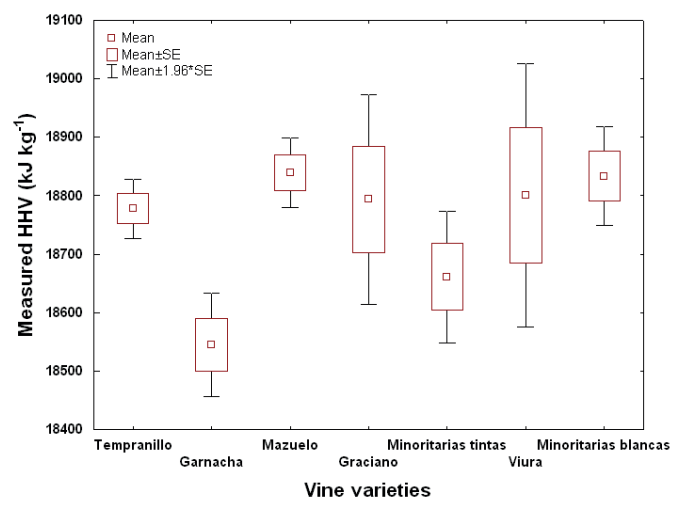

Figure 1. HHV of different varieties of vine shoots.

whereas the ash content trended slightly in the opposite direction.

A correlation was formulated using a multiple linear regression analysis from the elemental composition and the ash content data obtained experimentally for the various lots of shoots.

After successive iterations, no expressions were obtained with adequate values of the square of 

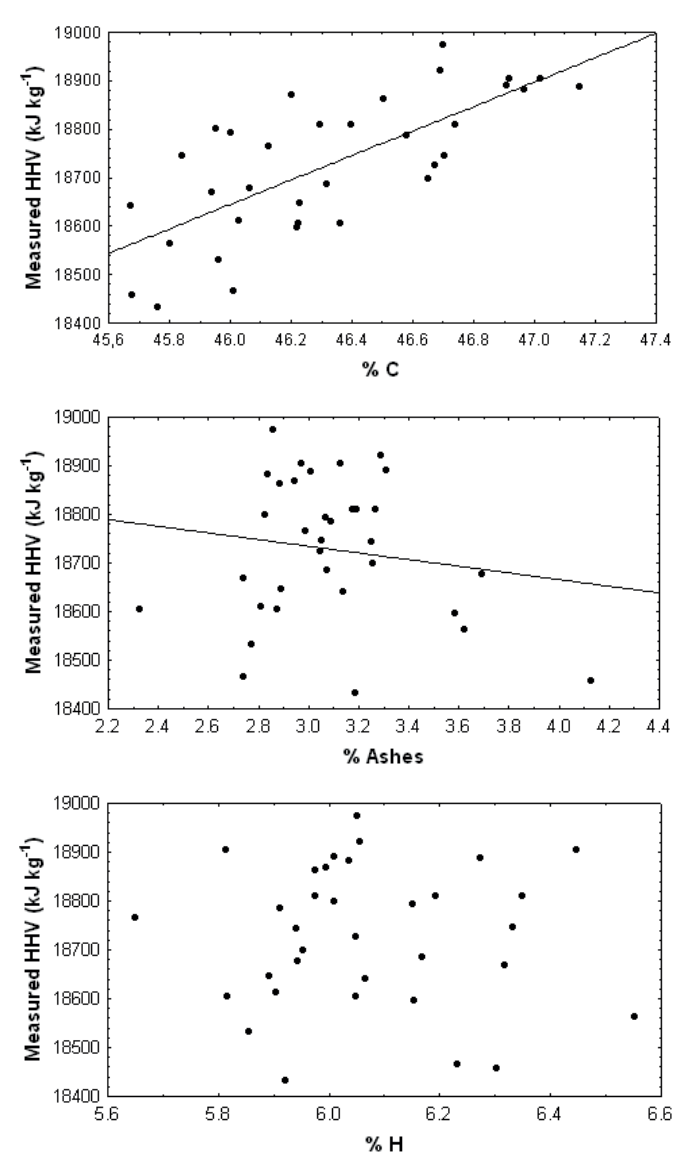

Figure 2. Scatter diagrams of the measured HHV versus the dry basis percentages of $\mathrm{C}$, ash content and $\mathrm{H}$ for Tempranillo vine shoot samples.

the Pearson correlation coefficient (adjusted $\mathrm{R}^{2}$ ). On the other hand, assuming that the independent term of the regression could be zero, the expression rapidly converged to an equation with acceptable results:

\section{$\mathrm{HHV}=370.8548 \cdot \mathrm{C}+267.4361 \cdot \mathrm{H} \quad\left(\mathrm{kJ} \mathrm{kg}^{-1}\right) \quad$ Eq.(1)}

In the previous formula, $\mathrm{C}$ and $\mathrm{H}$ are the percentages of carbon and hydrogen expressed on a dry basis, respectively. The other independent variables considered (dry basis percentages of $\mathrm{O}, \mathrm{N}, \mathrm{S}$ and ashes) were discarded because their corresponding $\mathrm{p}$-values were significantly higher than the adopted significance level (0.05). A comparison between the HHV measured in the laboratory and the estimated HHV from Eq. (1) is reflected in Figure 3.

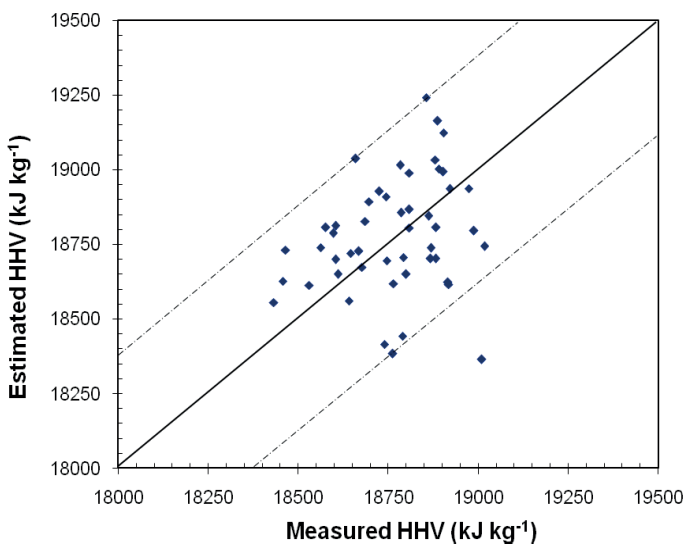

Figure 3. Measured HHV against estimated HHV using Eq. (1). The dashed lines delineate a relative error of $\pm 2 \%$.

Other formulas to estimate the HHV of biofuels were also selected from the scientific literature and were applied to compare their estimated HHV to the measured HHV (Tillman, 1978; Annamalai et al., 1987; Demirbas, 1997; Jenkins et al., 1998; Channiwala and Parikh, 2002; Friedl et al., 2005; Yin, 2011). The aforementioned AAE, $\mathrm{ABE}$ and SDE parameters were used to evaluate the accuracy of this new formula by the current authors and to compare it with correlations from the scientific literature. The usual indicator, $\mathrm{R}^{2}$, was not taken into account because the meaning of this parameter is not the same in the case of equations with or without an independent term (Marques de Sá, 2004). Table 2 shows the results of this comparison.

With the exception of Eq. (4), which produced some absolute errors (AAE) and a bias (ABE) of estimation greater than $8 \%$, the rest of the expressions predicted an HHV very close to the experimentally obtained result, with errors no greater than 2\%. Equation (2) and Eq. (6) produced a higher standard deviation of error (SDE), thus they would be less desirable. Among the rest, Eq. (7) from Sheng and Azevedo (2005), and Eq. (10) from Yin (2011), were particularly accurate; unfortunately, these two correlations were developed from data of unspecified biomass samples that were extracted from the scientific literature. Logically, new Eq. (1), which has been calculated from only vine shoots samples, was 
Table 2. Correlations used to predict the HHV from an elemental analysis.

\begin{tabular}{|c|c|c|c|c|c|}
\hline Ref. & Equation & Cited & AAE & $\mathrm{ABE}$ & SDE \\
\hline Eq. (1) & $\mathrm{HHV}=370.85 \mathrm{C}+267.44 \mathrm{H}$ & Current authors & 1.0 & 0.0 & 240 \\
\hline Eq. (2) & $\mathrm{HHV}=351.6 \mathrm{C}+1162.25 \mathrm{H}-110.9 \mathrm{O}+62.8 \mathrm{~N}+104.65 \mathrm{~S}$ & Annamalai et al. (1987) & 2.1 & -1.7 & 420 \\
\hline Eq. (3) & $\mathrm{HHV}=437.3 \mathrm{C}-1670.1$ & Tillman (1987) & 1.3 & -1.1 & 266 \\
\hline Eq. (4) & $\mathrm{HHV}=335 \mathrm{C}+1423 \mathrm{H}-154 \mathrm{O}-145 \mathrm{~N}$ & Demirbas (1997) & 8.4 & -8.4 & 486 \\
\hline Eq. (5) & $\mathrm{HHV}=-763+301 \mathrm{C}+525 \mathrm{H}+64 \mathrm{O}$ & Jenkins et al. (1998) & 2.0 & 1.9 & 201 \\
\hline Eq. (6) & $\mathrm{HHV}=349.1 \mathrm{C}+1178.3 \mathrm{H}+100.5 \mathrm{~S}-103.4 \mathrm{O}-15.1 \mathrm{~N}-21.1 \mathrm{~A}$ & Channiwala and Parikh (2002) & 1.7 & -0.7 & 414 \\
\hline Eq. (7) & $\mathrm{HHV}=-1367.5+313.7 \mathrm{C}+700.9 \mathrm{H}+31.8 \mathrm{O}$ & Sheng and Azevedo (2005) & 1.0 & 0.1 & 247 \\
\hline Eq. (8) & $\mathrm{HHV}=19914-232.4 \mathrm{~A}$ & Sheng and Azevedo (2005) & 1.3 & -1.2 & 212 \\
\hline Eq. (9) & $\mathrm{HHV}=3.35 \mathrm{C}^{2}-232 \mathrm{C}-2230 \mathrm{H}+51.2 \mathrm{C} \times 131 \mathrm{H}+20,600$ & Friedl et al. (2005) & 2.0 & -2.0 & 246 \\
\hline Eq. (10) & $\mathrm{HHV}=294.9 \mathrm{C}+825 \mathrm{H}$ & Yin (2011) & 1.3 & -0.8 & 278 \\
\hline
\end{tabular}

In all the equations, $\mathrm{C}, \mathrm{H}, \mathrm{N}, \mathrm{O}, \mathrm{S}$ are the percentages of these elements, and $\mathrm{A}$ is the ash content percentage, which is always expressed on a dry basis.

The average absolute error (AAE) and the average bias error (ABE) are expressed in percentages. The higher heating value (HHV) and the standard deviation of the prediction error (SDE) are expressed in $\mathrm{kJ} \mathrm{kg}^{-1}$.

the most accurate, with a mean absolute error of $1 \%$ and a null bias error.

\section{Energy potential of vine shoots of La Rioja}

As has been clearly revealed, vine shoots from La Rioja constitute an interesting raw material for the production of fuel. For the predominant variety (Tempranillo), representing almost $80 \%$ of the total production, an HHV of $18,778 \mathrm{~kJ} \mathrm{~kg}^{-1}$ was projected. This result indicates that vine shoots could become an attractive solid biofuel.

Having taken into account the amount of available vine shoots, their calorific value, moisture content and the usual harvest conditions, the energy potential of the annual production of vine shoots from the La Rioja vineyards is estimated at $1,400,000$ GJ.

Because the geographical distribution of the vineyards is well established by the aforementioned Oficina de Viñedo, we created an energy density map per municipality, which is shown in Figure 4. Because it is an intensive magnitude, the energy density provides additional information about the possible location of collection and energy generating plants. As seen on this map, pruned vine shoots are concentrated in a narrow strip on the studied territory, which further increases the potential value of this residue.

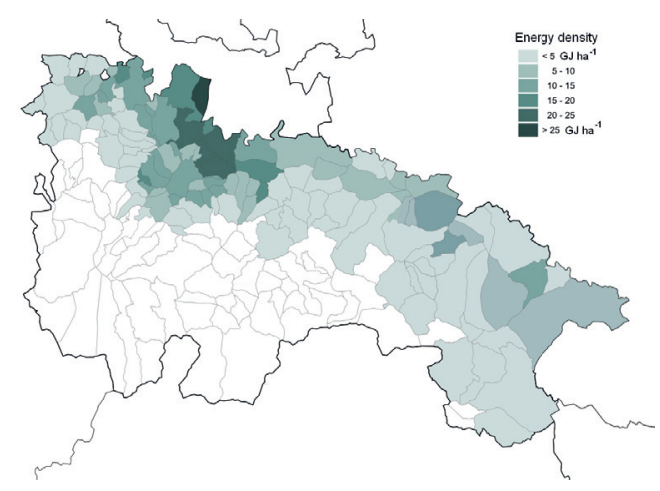

Figure 4. Annual energy density of vine shoots in La Rioja (Spain), in GJ ha-1.

\section{Acknowledgements}

The researchers would like to thank the following for support: CONICYT-FONDECYT Iniciación project number 11.140.728, Consejo Regulador de la Denominación de Origen Calificada Rioja, Spain (Control Board for the Designation of Rioja Origin) and especially to E. García-Escudero from the Instituto de Ciencias de la Vid y el Vino, Spain (Research Centre of Vine and Wine-related Science). 


\title{
Resumen
}

\begin{abstract}
M.A. Mendívil, P. Muñoz, M.P. Morales y M.C. Juárez Castelló. 2015. Potencial energético del sarmiento de vid de La Rioja (España) y su dependencia de diversos factores vitícolas. Cien. Inv. Agr. 42(3): 443-451. Cada año se generan miles de toneladas de sarmientos en la región española de La Rioja, sin que se hayan desarrollado aún sistemas adecuados para un razonable aprovechamiento de los mismos. El presente estudio intenta revalorizar esta biomasa residual, principalmente desde el punto de vista energético. Para ello, se ha realizado un muestreo representativo de las variedades y viñedos de la región y una posterior caracterización termoquímica, obteniéndose la humedad, el porcentaje de cenizas, la composición elemental y el poder calorífico para todos los lotes muestreados. Así se ha podido determinar que sólo el factor variedad tiene alguna influencia estadísticamente significativa. Se ha formulado una correlación que expresa el poder calorífico superior del sarmiento de vid en función de su composición elemental, consiguiendo una estimación con un error absoluto medio del 1\% y un error de sesgo medio nulo. Por último, conocida también la generación de sarmientos en el territorio de La Rioja, se ha estimado su potencial energético en 1.400.000 GJ térmicos anuales y se ha confeccionado el mapa de la densidad energética de este residuo por municipios.
\end{abstract}

Palabras clave: Caracterización termoquímica, poder calorífico, potencial energético, sarmientos de vid.

\section{References}

Annamalai, K., J.M. Sweeten, and S.C. Ramalingam. 1987. Estimation of gross heating values of biomass fuels. Transactions of ASAE 30:1205-1208.

Channiwala, S.A., and P.P. Parikh. 2002. An unified correlation for estimating $\mathrm{HHV}$ of solid, liquid and gaseous fuels. Fuel 81:1051-1563.

Consejo Regulador de la Denominación de Origen Calificada Rioja. 2014. Estadísticas de 2013. El Rioja en cifras. Available online at: http:// es.riojawine.com/multimedia/files/publicaciones/Estadisticas_Rioja_2013.pdf (Website accessed on May 2, 2014).

Demirbas, A. 1997. Calculation of higher heating value of biomass fuels. Fuel 76-5:431-434.

Ebeling, J.M., and B.M. Jenkins. 1985. Physical and chemical properties of biomass. Transactions of ASAE 23:898-902.

European Committee for Stardardization. 2009a. EN 14774-3:2009. Solid biofuels - Determination of moisture content - Oven dry method - Part 3: Moisture in general analysis simple. Comité Européen de Normalisation, Bruxelles.

European Committee for Stardardization. 2009b. EN 14775:2009. Solid biofuels - Determination of ash content. Comité Européen de Normalisation, Bruxelles.

European Committee for Stardardization. 2009c. EN 14918:2009. Solid biofuels - Determination of calorific value. Comité Européen de Normalisation, Bruxelles.

European Committee for Stardardization. 2011. EN 15104:2011.Solid biofuels - Determination of total content of carbon, hydrogen and nitrogen Instrumental methods. Comité Européen de Normalisation, Bruxelles.

Friedl, A., E. Padouvas, H. Rotter, and K. Varmuzza. 2005. Prediction of heating values of biomass fuel from elemental composition. Analytica Chimica Acta 544:191-198.

Jenkins, B.M., L.L. Baxter, T.R. Miles Jr., and T.R. Miles. 1998. Combustion properties of biomass. Fuel Processing Technology 54:17-46.

Marques de Sá, J.P. 2004. Applied Statistics using SPSS, STATISTICA and MATLAB. SpringerVerlag, Berlin. 505 pp.

Martínez de Toda, F. 2007. Claves de la viticultura de calidad: nuevas técnicas de estimación y control de la calidad de la uva en el viñedo. MundiPrensa, Madrid. 242 pp.

Mediavilla, I., M.J. Fernández, and L.S. Esteban. 2009. Optimization of pelletisation and combus- 
tion in a boiler of $17.5 \mathrm{~kW}_{\text {th }}$ for vine shoots and industrial cork residue. Fuel Processing Technology 90:621-628.

Mendívil, M., P. Muñoz, M.P. Morales, and M.C. Juárez. 2011. Estudio del potencial energético del sarmiento de vid de La Rioja. Libro de Actas del VII Congreso Nacional de Ingeniería Termodinámica. Bilbao, Spain.

Ramos, J.J. 2009. Sarmientos de viña. Aprovechamiento energético. The Bioenergy International 1:38.

San José, M.J., S. Álvarez, I. García, and F.J. Peñas.
2013. A novel conical combustor for thermal exploitation of vineyard pruning wastes. Fuel 110:178-184.

Sheng, C., and J.L. Azevedo. 2005. Estimating the higher heating value of biomass fuels from basic analysis data. Biomass and Bioenergy 28:499507.

Tillman, D.A. 1978. Wood as an energy resource. Academic Press, New York. 252 pp.

Yin, C. 2011. Prediction of higher heating values of biomass from proximate and ultimate analyses. Fuel 90:1128-1132. 
